\title{
SISTEM INFORMASI GEOGRAFIS PENERAPAN HEATMAP DAN PEMETAAN PADA LOKASI PENDERITA HIV/AIDS DI KABUPATEN MALANG BERBASIS ANDROID
}

\author{
Aldi Setyawan Dwi R Fajri, Ahmad Faisol, Renaldi Primaswara Prasetya \\ Program Studi Teknik Informatika S1, Fakultas Teknologi Industri \\ Institut Teknologi Nasional Malang, Jalan Raya Karanglo km 2 Malang, Indonesia \\ Aldo.ftr8@gmail.com
}

\begin{abstract}
ABSTRAK
Sistem informasi geografis saat ini sudah berkembang sangat pesat seiring dengan berkembangnya jaman. Dan sekarang sistem informasi geografis sendiri sudah sangat berfariasi dengan berbagai model dan yang sekarang terlihat kebanyakan sistem informasi geografis ini berbasis web. Untuk itu diperlukan inovasi terbaru yaitu sistem informasi geografis berbasis mobile web. Agar lebih efisien dan efektif.

Pada pembuatan sistem informasi geografis penerapan heatmap dan pemetaan pada lokasi penderita hiv/aids di kabupaten malang berbasis android ini dikembangkan dengan peta yang dibuat secara manual dengan arcgis dan di terapkan Heatmap lalu di konfersikan ke web. Setelah itu peta di koneksikan dengan android dengan menggunakan webview ini lebih efisien karena tidak perlu lagi membuka web sistem informasi geografis karena sudah berbasis android.

Selain itu Heatmap yang diterapkan pada peta juga sangat membantu karena heatmap ini menampilkan informasi penderita HIV/AIDS di kabupaten Malang berdasarkan warna yaitu hijau (status aman), kuning (waspada), merah (bahaya) cara kerja heatmap inipun berdasarkan tingkat penderita HIV/AIDS jka sanngat banyak penderita maka akan berwarna merah dan jika sedikit penderita atau tidak ada maka akan berwarna hijau. Sehingga ini sangat membantu sekali dan mudah dipahami.
\end{abstract}

Kata Kunci : penerapan heatmap berbasis android

\section{PENDAHULUAN}

HIV dan AIDS. HIV ( Human Immunodeficiency Virus ) sedangkan AIDS ( Acquired Immune Deficiency Syndrome ). HIV ( Human Immunodeficiency Virus ) sendiri adalah virus yang merusak sistem kekebalan tubuh sehingga tubuh akan semakin lemah dan penderita yang terserang virus ini rentan diserang oleh berbagai penyakit dan kemungkinan akan terjadinya komplikasi. AIDS ( Acquired Immune Deficiency Syndrome ) ini adalah stadium akhir dari infeksi virus HIV. Pada tahap ini tubuh akan sepenuhnya kehilangan kekebalan tubuh.

Cara penyebaran virus inipun dapat melalui hubungan intim tanpa alat pengaman, melalui produk darah seperti penggunaan jarum suntik yang tidak steril dan dari ibu ke bayi. Gejala yang di timbulkan oleh virus ini ke orang yang terinfeksi juga membutuhkan waktu beberapa minggu untuk tahap awal. Virus ini juga memiliki beberapa gejala-gejala awal seperti demam dan flu dengan suhu tubuh yang sangat tinggi sekitar 38 derajat celcius. Kelelahan karena sistem kekebalan tubuh terus-menerus melawan virus. Dan juga nyeri pada kelenjar getah bening dan otot.

Dan sampai saat ini virus ini belum ditemukan penanggulangan yang pasti seperti obat atau vaksin yang menjamin kesembuhan total dari pendertia virus ini seperti kebanyakan sakit-sakit pada umumnya. Maka untuk mencegah agar tidak terkena virus HIV ini yaitu pastinya menjaga kebersihan dan kesehatan tubuh, tidak menggunakan obat-obat terlarang dengan media suntik seperti narkoba dan sejenisnya, berhubungan intim dengan memakai alat pengaman. maka akan dibuatnya sebuah sistem geografis penerapan heatmap dan pemetaan pada lokasi penderita hiv/aids di kabupaten malang berbasis android.

sistem geografis penerapan heatmap dan pemetaan pada lokasi penderita hiv/aids di kabupaten malang berbasis android. Sistem informasi geografis ini memetakan dan menganalisis di seluruh kabupaten malang diamana saja yang terkena virus HIV ini.memberikan informasi dan juga memudahkan masyarakat.

\section{TINJAUAN PUSTAKA}

\subsection{Penelitian Terdahulu}

Sebelumnya, telah ada penelitian Subastian Wibowo1, M. Syafri Lamato, Afu Ichsan Pradana, Rifqi Mizan Aulawi, Toto Indriyatmoko, Ema Utami. yang berjudul "Perancangan Sistem Informasi Geografis Penyebaran Penyakit Oleh Nyamuk di Provinsi Daerah Istimewa Yogyakarta", mengatakan bahwa banyak penyebaran nyamuk yang menyebabkan penyakit DBD ( demam berdarah ) ini tidak bisa di monitoring oleh dinas kesehatan karena penyebaran yang tidak tertentu sehingga tidak dapat dipastikan dimana saja penyebarannya.. Oleh sebab tersebut, maka dibuatlah sebuah Perancangan Sistem Informasi Geografis Penyebaran Penyakit Oleh 
Nyamuk di Provinsi Daerah Istimewa Yogyakarta. Dari hasil penelitian dapat merancang model sebuah aplikasi sistem informasi geografis penyebaran penyakit yang disebabkan oleh nyamuk di propinsi Daerah Istimewa Yogyakarta. Perancangan ini diharapkan dapat menghasilkan sistem informasi yang memberikan informasi data spasial berupa peta kepada masyarakat untuk penyebaran penyakit yang disebabkan oleh nyamuk diantaranya Demam Berdarah, Cikungunya, Malaria, dan Kaki Gajah. [1]

Irfan Abbas, pada penelitiannya yang berjudul "sistem informasi geografis berbasis mobile android untuk pemetaan lokasi pengrajin kerajinan tangan khas gorontalo", menjelaskan bahwa kota gorontalo adalah kota yang sangat kreatif dalam menghasilkan sebuah ide-ide dan mengimplementasikannya menjadi sebuah kerajinan yang unik khas gorontalo. Sebelumnya kota gorontalo ini adalah kota yang kekurangan sumberdaya alam dan juga tingkat kemiskinan yang sangat tinggi dan pada kurun waktu 15 tahun kota gorontalo dapat membuktikan dan membuat struktur otonomi daerah yang lebih baik. Tapi masalahnya yaitu susahnya mencari oleh-oleh khas sana dan oleh sebab itu sehingga dibuatnya aplikasi ini dan mencantumkan koordinat pengrajin agar memudahkan masyarakat atau turis untuk dengan mudah mencari oleh-oleh khas tangan gorontalo.[2]

Pada tahun 2018, Susanto, pada penelitiannya yang berjudul " Sistem Informasi Geografis Pemetaan Kantor Dinas di Kota Lubuklinggau Berbasis Android. Pada penelitiannya ini dia menjelaskan bahwa kota Lubuklinggau adalah suatu kota yang berkembang setingkat kabupaten paling barat wilayah propinsi Sumatera Selatan yang terletak pada pada posisi antara 102040 ' 0"- 1030 0' 0" bujur timur dan 30 4' 10 "- 30 22' 30" lintang selatan. Kota ini banyak didatangi oleh pendatang dan investor yang kesulitan mencari kantor dinas sehingga membutuhkan waktu yang cukup lama. Metode yang digunakan pada penelitian ini menggunakan metode waterfall kenapa karena pada metode ini rancangan sistem untuk menghindari kesalahan sangatlah kecil karena pembuatan sistem yang secara bertahap atau terstruktur dengan baik. Hasil dari penelitian ini yaitu menampilkan titik-titik koordinasi kantor dinas, jarak dan lama perjalanan untuk sampai ke kantor dinas yang di tuju. [3]

Pada tahun 2017 Teknik Informatika dan Komputer,Politeknik Negeri Jakarta J1. Prof.Dr.G.A.Siwabessy, Kampus Baru UI Depok, Jakarta pada penelitianya yang berjudul "pemanfaatan sistem informasi geografis (sig) dalam aplikasi pelaporan dan pelacakan kejahatan berbasis android". Pada penelitiannya ini menjelaskan bahwa tingkat kejahatan yang terjadi sangatlah besar bahkan rata-rata tindak kejahatan terjadi setiap 1 menit 36 detik pada tahun 2014. Sehingga mereka melakukan penelitian dan membuat fasilitas pada projek android yang mereka buat yaitu panic button. Metode yang dipakai pada penelitian ini juga memakai metode google maps API. Hasil dari peneltian ini juga sangat bagus sekali karena pada penelitian mereka hasil yang di tampilkan yaitu hasil pelaporan dan pelacakan berbasis android. [4]

Di tahun 2017 juga Diah Aryani dan kawankawan melakukan sebuah penelitian yang berjudul "Perancangan Android Package Mobile Web pada Sistem Penilaian di Perguruan Tinggi" penelitian yang dijalani mereka yaitu menjelaskan bahwa seiring perkembangan teknologi yang semakin maju masih banyak yang belum menggunakan sistem informasi berbasis android mobile untuk penilaian agar lebih efisien. Dengan menggunakan Android Package. Android Package adalah sebuah format berkas yang digunakan untuk mendistribusikan dan memasang software dan middleware ke smartphone dengan sistem operasi Android. metode HTTP Connection dan JSON Parsing. Pembuatan aplikasi menggunakan bahasa pemrograman Java, dengan bantuan tools IDE Eclipse dan MySQL untuk database server. Hasil yang diperoleh berjalan dengan baik web yang sudah di konversi ke android dan dapat di akses dengan bebas dan juga pengisian data penilaian juga lebih efisien. [5]

\subsection{Dasar Teori \\ 2.2.1 QGIS}

QGIS merupakan perangkat lunak untuk sistem informasi geografis yang bersifat open source dan gratis. QGIS atau yang dulunya dikenal sebagai Quantum GIS software ini adalah sebuah perangkat lunak yang dimana digunakan dalam memanipulasi data sebuah peta yang akan dibuat. perangkat lunak ini juga sangat mudah digunakan dikarenakan fasilitas-fasilitas yang sudah disediakan di dalamnya juga sudah sangat lengkap dimana peta yang dibuat dapat diolah berdasarkan warna, memasukan data peta, menentukan koordiant peta dan juga membuat peta menjadi sebuah web.

\subsubsection{Arcgis}

Perangkat lunak ArcGIS merupakan perangkat lunak SIG yang baru dari ESRI (Environmental Systems Research Institute), yang memungkinkan pengguna untuk memanfaatkan data dari berbagai format data. Dengan ArcGIS pengguna dapat memanfaatkan fungsi desktop maupun jaringan, selain itu juga pengguna bisa memakai fungsi pada level ArcView, ArcEditor, ArcInfo dengan fasilitas ArcMap, ArcCatalog dan Toolbox 


\subsubsection{Android}

Android adalah susatu sistem operasi. Sitem operasi ini berbasis linux khusus untuk handphone jadi android ini menyediakan fasilitas atau platform untuk siapa saja yang ingin mengembangkan atau membuat suatu aplikasi sendiri yang nantinya aplikasi ini dapat bermanfaat bagi masyarakat atau di pakai sendiri. Android juga memiliki beberapa bahasa pemrograman yaitu PHP, Javascript dll. Untuk pengoperasian suatu aplikasi. Android sendiri tergolong suatu software yang lumayan berat dalam artian membutuhkan spesifikasi laptop yang bagus minimal RAM 8 Gb. Kenapa demikian karena jika spesifikasi laptop tidak memadai maka aplikasi ini ketika dijalankan akan sangat lama.

\section{ANALISIS DAN PERANCANGAN}

\subsection{Desain Arsitektur Sistem}

dalam desain arsitektur sistem terdapat tiga tahap yaitu input, proses, dan output seperti yang ada di gambar 1 di bawah ini

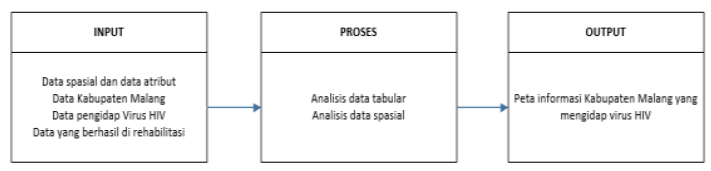

Gambar 1 Arsitektur sistem

\subsection{Desain Sistem}

Ini merupakan sebuah tampilan yang nantinya akan dibuat di android.

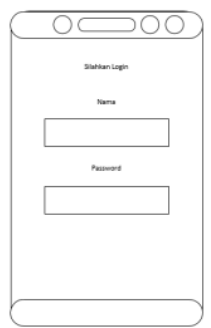

Gambar 2 Tampilan Login

a. Tampilan utama

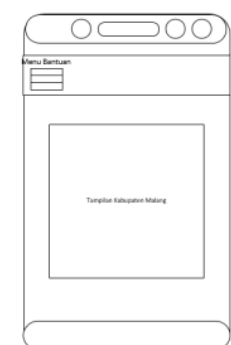

Gambar 3 Tampilan utama

\subsection{Flowchart Sistem}

Flowchart sistem ini menjelaskan proses berjalananya aplikasi seperti ditunjukkan pada Gambar 3.

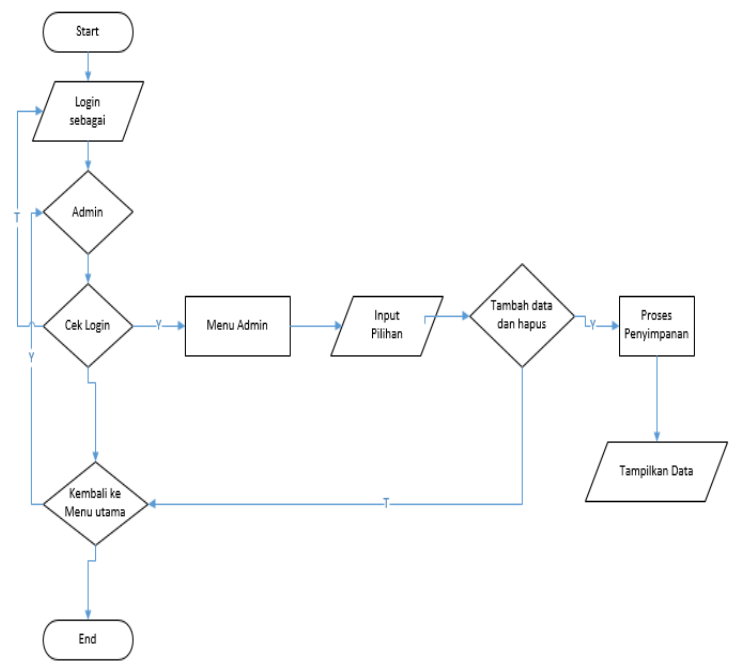

Gambar 4 Flowchart Sistem

gambar 3 flowchart sistem informasi geografis sistem informasi geografis penerapan heatmap dan pemetaan pada lokasi penderita hiv/aids di kabupaten malang berbasis android ini diawali dengan login admin dan user. Setelah itu jika admin login maka akan di cek, jika kondisi Y maka admin akan masuk ke tampilan login admin jika kondisi $\mathrm{T}$ maka akan kembali ke login sebagai. Jika admin ingin menambah dan menghapus data data admin perlu login terlebih dahulu maka akan masuk ke pilihan menu menambah data dan menghapus data lalu data akan di tampilkan jika tidak maka akan kembali ke menu utama. Unutk user maka akan langsung ke menu utama

\section{HASIL DAN PEMBAHASAN}

4.1 Pembuatan peta pada arcgis

Membuat peta Malang secara manual menggunakan arcgis. Menentukan koordinat peta Malang yang di buat, membuat pembagian daerah peta berdasarkan kabupaten dengan perbedaan warna agar mudah di ketahui. Dan penentuan setiap daerah menggunakan point. Seperti pada Gambar 5 tampilan peta malang dengan arcgis.

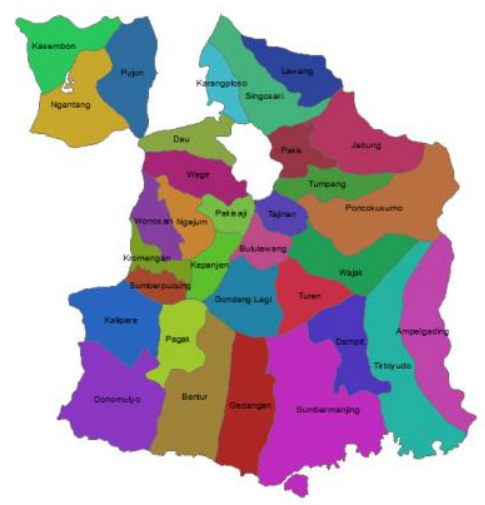

Gambar 5 tampilan peta malang dengan arcgis 
Pengkoneksian peta arcgis dengan Web Peta arcgis yang telah dibuat tadi di save menggunakan format shp. Setelah itupeta akan di tampilkan ke web. Terlihat seperti pada Gambar 6 Tampilan peta malang pada web.

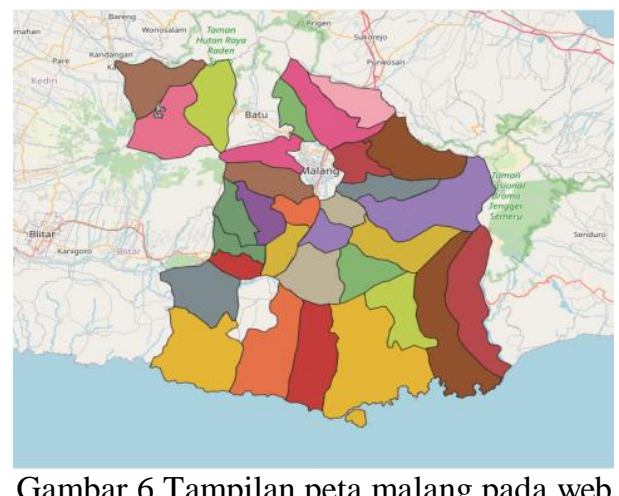

\subsection{Pembuatan tampilan pada android}

Beberapa tammpilan yang sudah dibuat pada andorid meliputi beberapa tampilan yaitu login admin, tampilan gejala penyakit HIV/AIDS, tampilan penyebaran dan juga pengertian HIV/AIDS. Tampilan login admin dapat dilihat pada Gambar 7 tampilan login admin.

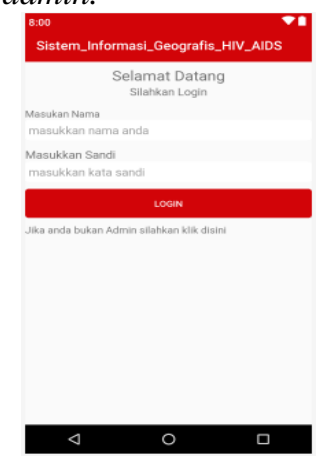

Gambar 7 tampilan Login Admin

Tampilan ini berfungsi sebagai tampilan yang nantinya admin dapat mengisi data-data penyebaran pada area malang.

\subsection{Tampilan pengertian HIV/AIDS}

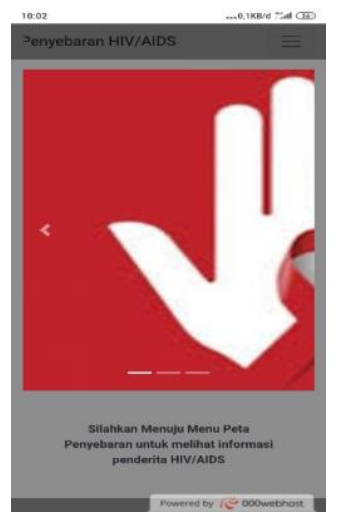

Gambar 8 tampilan utama HIV/AIDS
Tampilan ini adalah tampilan awal dimana nantinya dapat dilihat user pertama kali

\subsection{Tampilan penyebaran HIV/AIDS}

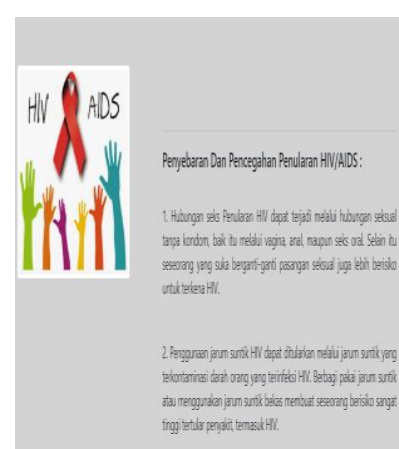

Gambar 9 Tampilan penyebaran HIV/AIDS

Pada tampilan ini user dapat melihat bagaimana cara penyebaran atau penularan HIV/AIDS.

\subsection{Tampilan gejala HIV/AIDS}

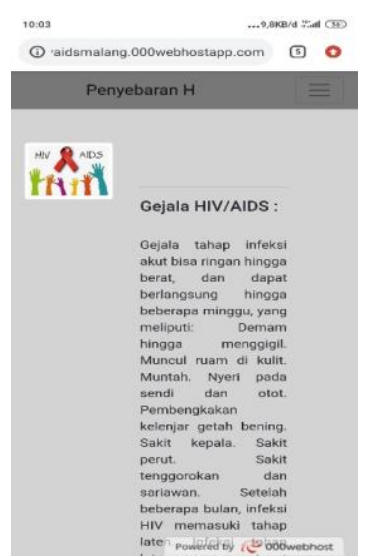

Gambar 10 tampilan Gejala HIV/AIDS

Pada tampilan ini user dapat melihat beberapa gejala yang dapat diakibatkan oleh HIV/AIDS.

\subsection{Tampilan peta dengan heatmap}

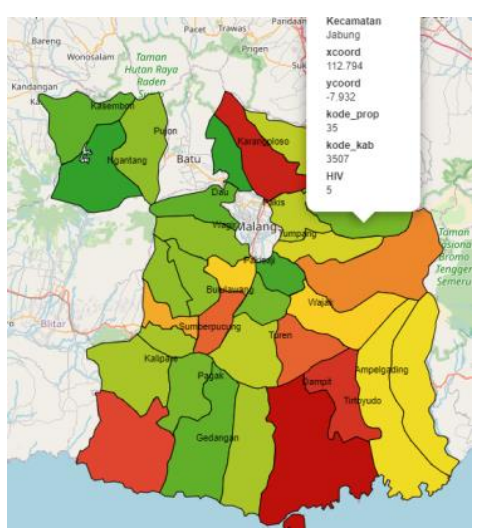

Gambar 4.11 tampilan peta Malang di Heatmap 
Pada tampilan ini peta yang telah di buat dengan arcmap 10.6.1 dan di terapkan heatmap maka akan terlihat seperti pada Gambar 4.7 tampilan peta Malang di Heatmap dan di koneksikan ke android.

\subsection{Tampilan pengertian HIV/AIDS}

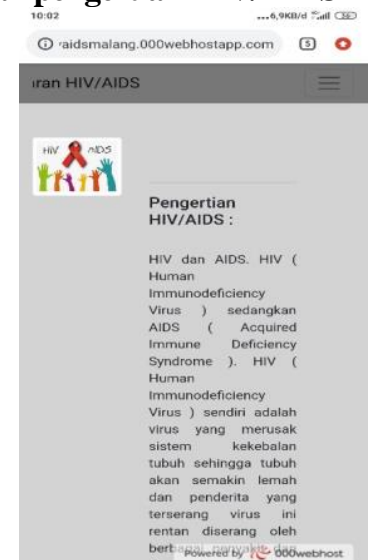

Gambar 4.12 tampilan pengertian HIV/AIDS

Pada tampilan ini dimana nantinya user dapat mengetahui apa itu HIV/AIDS

\subsection{Tampilan Edukasi}

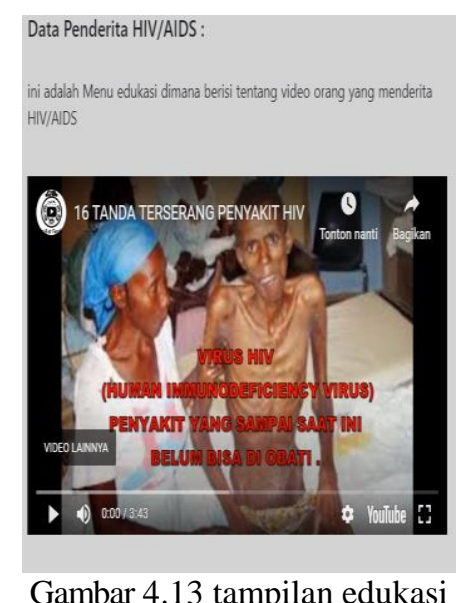

Pada tampilan ini user dapat melihat bagaimana virus HIV/AIDS menyerang seseorang

\subsection{Pengujian Fungsional}

\begin{tabular}{|c|c|c|c|c|}
\hline \multirow[b]{2}{*}{ No } & \multirow[b]{2}{*}{ Item Yang Di Uji } & \multicolumn{3}{|c|}{ Versi OS } \\
\hline & & $\begin{array}{c}\text { Android Oreo } \\
8.1\end{array}$ & $\begin{array}{c}\text { Android Pie } \\
9.0\end{array}$ & Android 10 \\
\hline 1 & Halaman Login Admin & $\checkmark$ & $\checkmark$ & $\checkmark$ \\
\hline 2 & $\begin{array}{lll}\text { Halaman peta Malang } \\
\text { Heatmap } & & \\
\end{array}$ & $\checkmark$ & $\checkmark$ & $\checkmark$ \\
\hline 3 & $\begin{array}{ll}\text { Halaman } & \text { penyebaran } \\
\text { HIV/AIDS } & \end{array}$ & $\checkmark$ & $\checkmark$ & $\checkmark$ \\
\hline 4 & $\begin{array}{ll}\text { Halaman } & \text { gejala } \\
\text { HIV/AIDS } & \end{array}$ & $\checkmark$ & $\checkmark$ & $\checkmark$ \\
\hline 5 & $\begin{array}{ll}\text { Halaman } & \text { pengertian } \\
\text { HIV/AIDS } & \end{array}$ & $\checkmark$ & $\checkmark$ & $\checkmark$ \\
\hline
\end{tabular}

\section{KESIMPULAN DAN SARAN}

\subsection{Kesimpulan}

Berdasarkan analisa yang telah dilakukan pada sistem informasi geografis penerapan heatmap dan pemetaan pada lokasi penderita hiv/aids di kabupaten malang berbasis android. Maka dapat diambil kesimpulan sebagai berikut.

1. Sistem informasi geografis dapat bermanfaat dan efektif dalam membantu masyarakat khususnya untuk persebaran penderita HIV/AIDS di kabupaten Malang

2. Sistem dapat memberikan informasi penderita HIV/AIDS di kabupaten Malang

3. Arcgis yang dipakai sangat memudahkan dalam pembuatan peta

4. QGIS dapat memudahkan peta yang dibuat pada arcgis di konversikan ke web.

5. Hasil pengujian penerapan heatmap di QGIS menunjukan hasil berjalan dengan baik

6. Hasil pengujian fungsional menunjukan hasil $80 \%$

7. Hasil pengujian fungsional pada android Oreo 8.1 menunjukan hasil berjalan dengan baik

8. Hasil pengujian fungsional pada android Pie 9.0 berjalan dengan baik

9. Hasil pengujian fungsional pada android 10 berjalan dengan baik

\subsection{Saran}

Berdasarkan penelitian yang telah dilakukan, maka penulis dapat memberikan saran-saran untuk pengembangan selanjutnya antar lain :

1. Untuk pengembangan kedepannya lebih baiknya diberikan fasilitas konsultasi agar ketika masyarakat merasa mengalami beberapa gejala HIV/AIDS bisa langsung konsultasi.

2. Sistem informasi geografis ini perlu titik koordinat user agar dapat mengetahui posisi user ketika berada di wilayah yang merupakan zona penderita HIV/AIDS.

3. Sistem informasi geografis ini perlu di buat online agar titik koordinat user dapat terbaca.

\section{DAFTAR PUSTAKA}

[1] Susanto. Sistem Informasi Geografis Pemetaan Kantor Dinas di Kota Lubuklinggau Berbasis Android. Jurnal Mahasiswa Teknik Informatika, Volume VI, Nomor 1, Mei 2018.

[2] Irfan Abbas. sistem informasi geografis berbasis mobile android untuk pemetaan lokasi pengrajin kerajinan tangan khas gorontalo. Jurnal Manajemen Informatika. jurnal informatika upgris vol. 3, no. 2, (2017).

[3] Subastian Wibowo, M. Syafri Lamato, Afu Ichsan Pradana, Rifqi Mizan Aulawi, Toto Indriyatmoko, Ema Utami. Perancangan Sistem Informasi Geografis Penyebaran Penyakit Oleh Nyamuk di Provinsi Daerah Istimewa Yogyakarta. Volume 10 Nomor 1 April 2016. 
[4] Ummi Athiyyah Yuniarti, Bambang Sudarsono, Arwan Putra Wijaya. " aplikasi sistem informasi geografis penyebaran penyakit demam berdarah dengue berbasis web". Volume 3, Nomor 3, Tahun 2014.

[5] Sistem Informasi Geografis. Available: http://developers.google.com/maps/docume
ntation/android/start,[Diakses 20 september 2016].

[6] Teknik Informatika dan Komputer,Politeknik Negeri Jakarta Jl. Prof.Dr.G.A.Siwabessy, Kampus Baru UI Depok, Jakarta kholil.ibnu@gmail.com pemanfaatan sistem informasi geografis (sig) dalam aplikasi pelaporan dan. Vol.6 No. 1, Juni 2017 : 51 - 58 